\title{
Altered Patterns of Gene Expression in Arabidopsis Elicited by Cauliflower Mosaic Virus (CaMV) Infection and by a CaMV Gene VI Transgene
}

\author{
Chiara Geri, ${ }^{1,3}$ Edi Cecchini, ${ }^{1}$ Maria E. Giannakou, ${ }^{1}$ Simon N. Covey, ${ }^{2}$ and Joel J. Milner ${ }^{1}$ \\ ${ }^{1}$ Plant Molecular Science Group, Division of Biochemistry and Molecular Biology, Institute of Biomedical and \\ Life Sciences, Glasgow University, Glasgow G12 8QQ, Scotland, U.K.; ' John Innes Centre, Colney Lane, \\ Norwich, NR7 4UH, U.K.; ${ }^{3}$ Istituto di Mutagenesi e Differenziamento, C.N.R., Via Svezia 5, 56122 Pisa, \\ Italy \\ Accepted 21 January 1999.
}

Cauliflower mosaic virus (CaMV) gene VI protein (P6) is an important determinant of symptom expression. Differential display polymerase chain reaction (PCR) was used to identify changes in gene expression in Arabidopsis elicited by a P6 transgene that causes a symptomatic phenotype. We used slot blot hybridization to measure the abundance of mRNAs complementary to 66 candidate PCR products in transgenic, CaMV-infected, and uninfected Arabidopsis plants. CaMV-infected and P6 transgenic plants showed broadly similar changes in abundance of mRNA species. In P6 transgenic plants we detected 18 PCR products that showed unambiguous changes in abundance plus another 15 that showed more limited changes (approximately twofold). CaMV-infected plants showed 17 unambiguous and 13 limited changes. Downregulated species include those encoding a novel, phenollike sulfotransferase, and a glycine-rich, RNA-binding protein. Up-regulated species included ones encoding an $m y b$ protein, glycine-rich and stress-inducible proteins, and a member of a previously unreported gene family. CaMV infection causes alterations in expression of many Arabidopsis genes. Transgene-mediated expression of P6 mimics virus infection in its effect on host gene expression, providing a potential mechanism for this process.

Additional keywords: amplified cDNA.

Accumulating evidence suggests that symptom development in plants might involve programmed changes in expression of host genes. Patterns of symptom expression are highly dependent on the genetic background of both the host and the virus (Cecchini et al. 1998), so that different isolates of the same virus are often able to induce symptoms that vary greatly in severity, despite there being little difference in levels of accumulation (Cecchini et al. 1998). Infection has been shown

Corresponding author: Joel J. Milner; Bower Building, Glasgow University, Glasgow G12 8QQ, Scotland, U.K.; Telephone: (+44) 141330 5836; Fax: (+44) 141330 4447; E-mail: joel.milner@bio.gla.ac.uk

Nucleotide and/or amino acid sequence data have been deposited with the EMBL data base as accession numbers ATH9555, AJ011669, and ATH6409. to alter the pattern of host gene expression (Wang and Maule 1995; Aranda et al. 1996), and responses such as gene silencing may be specifically connected to antiviral pathways (Covey et al. 1997; Al-Kaff et al. 1998; Ratcliff et al. 1997).

Until recently, little was known about the identity or nature of the genes involved in plant responses to infection by compatible viruses. However, evidence is beginning to emerge that indicates that virus spread is correlated with dramatic changes in cellular metabolism and gene expression (Wang and Maule 1995; Balachandran et al. 1997) and a number of genes have been identified whose level of expression is regulated by infection with compatible viruses (Zhu et al. 1995; Aranda et al. 1996). It is not known to what extent the viral symptoms are a cause or consequence of such changes. Despite recent advances in understanding virus replication, little is known about either signal transduction during plant responses to virus infection, or the mechanisms by which the symptom response is enacted.

Expression of viral genes in transgenic plants can elicit disease-like symptoms in the absence of virus infection (Cecchini et al. 1997; Goldberg et al. 1991; Krake et al. 1998). We have exploited this phenomenon to develop a model system in which transgene-mediated expression in Arabidopsis of a single cauliflower mosaic virus (CaMV)-encoded protein, P6, the product of viral gene VI, gives rise to a symptomlike phenotype in the absence of virus replication (Baughmann et al. 1988; Cecchini et al. 1997). P6 is a 62-kDa, multifunctional polypeptide with a primary role in viral protein synthesis. It has several functional domains, including a translational transactivator, an RNA-binding domain, and a zinc finger domain, each of which is essential for infectivity (Rothnie et al. 1994; Turner et al. 1996). In addition to its central role in CaMV multiplication, gene VI specifies disease phenotypes including symptom severity, leaf chlorosis, and dark greening, and it contains host-range determinants (Stratford and Covey 1989; Covey and Turner 1991; Anderson et al. 1991). Our strategy is to use transgenic Arabidopsis expressing a viral pathogenic determinant, rather than viral infection, to provide a more uniform response and develop new strategies to screen for mutant plant-pathogenic loci. To authenticate the use of transgenes to elicit host pathogenic responses, it is essential to compare the host response to the viral transgene with the re- 
sponse to viral infection. Analysis of changes in expression of host genes facilitates such a comparison and contributes to an understanding of the way plants respond to infection.

Differential display polymerase chain reaction (DD-PCR) provides a powerful method for the rapid identification of differentially expressed genes, and has been used successfully to identify such genes in both host and pathogen during Botrytis cinerea infections (Benito et al. 1996). In this paper, we report the use of DD-PCR to detect more than 30 genes whose level of expression is either up- or down-regulated as a result of transgene-mediated gene VI expression and CaMV infection. Poirier et al. (1997) described a technique, amplified RNA screening, that allows the rapid screening for expression levels of large numbers of candidate cDNAs identified by DD-PCR. We have developed a modification to the technique, amplified cDNA screening, that is both more sensitive and technically simpler, and have used it to compare levels of individual mRNAs in control, gene VI-transgenic, and CaMV-infected plants.

\section{RESULTS}

\section{DD-PCR.}

DD-PCR was carried out with, as template, RNA from the gene VI transgenic Arabidopsis line Baji-A15 and from uninfected, nontransgenic control plants. To optimize the efficiency, reproducibility, and yield of DD-PCR, reactions were carried out in an Air Thermo-Cycler. In preliminary experiments, repeated independent amplifications of batches of RNA from either control or transgenic plants reproducibly gave essentially identical patterns.

Using 24 primer combinations, we identified 149 bands with distinct differences in intensity between Baji-A15 and nontransgenic RNA templates (data not shown). Of these, 74 bands were more intense and 75 bands were less intense with the Baji-A15 template. Of the 106 products that we were able to re-amplify, 66 were selected for further analysis.

\section{Analysis of mRNA abundance.}

To confirm the results of the DD-PCR, differentially expressed cDNAs were analyzed by a modification of the amplified RNA dot blot hybridization procedure of Poirier et al. (1997). Triplicate filters were loaded with 33 PCR products plus three controls, pBluescript, pUC-Baji31 (containing the CaMV gene VI sequence), and pPvSS191 (containing an $r b c \mathrm{~S}$ cDNA), and hybridized with amplified RNA from CaMVinfected, P6-transgenic, and uninfected, nontransgenic controls. In our hands the procedure of Poirier et al. (1997) yielded only 2 to $5 \times 10^{6} \mathrm{dpm}$ of probe from each RNA template, and we could detect hybridization to only three PCR products, even after prolonged exposure (data not shown).

We adopted a modified procedure for probe synthesis. First, double-stranded (ds) DNA was synthesized from the RNA template. Then, multiple single-strand copies of the ds cDNA template were synthesized in a thermocycler with a single primer complementary to the T7 sequence. We obtained approximately $2.5 \times 10^{8} \mathrm{dpm}$ of single-stranded DNA probe from each synthesis reaction, 50 to 125 times as much as from the amplified RNA procedure. All three probes hybridized strongly to the $r b c \mathrm{~S}$ control, and none hybridized to the pBluescript control. Probes from Baji-A15 transgenic plants and CaMV-infected plants, but not uninfected, nontransgenic controls, hybridized strongly to pUC-Baji31 (Fig. 1).

Changes in Arabidopsis mRNA abundance are summarized in Table 1. Seventeen PCR products did not give a detectable hybridization signal, and are presumably derived from low abundance mRNAs. The remaining 49 hybridized to at least one of the probes. Thirty-one (of which two subsequently turned out to be duplicates) hybridized with different intensities to Baji-A15, compared with nontransgenic, uninfected control probes. Nine were obviously more and 8 obviously less abundant in the Baji-A15 probe. A further 8 and 6 species, respectively, showed smaller (approximately twofold) increases and decreases in hybridization.

Thirty PCR products hybridized with different intensities to CaMV-infected and uninfected, nontransgenic probes. Of these, 17 ( 8 obviously) were more abundant and 13 (9 obviously) less abundant in infected plants (Table 1). Ten of the species up-regulated in Baji-A15 transgenic plants were also up-regulated in CaMV-infected plants and 8 of the species down-regulated in Baji-A15 plants were also down-regulated in infected plants. With only two species, $11 \mathrm{~A}$ and $4 \mathrm{C}$, did we observe opposite changes in abundance between infected and transgenic plants.

\section{Identification of up- and down-regulated sequences.}

To identify mRNAs that were altered in abundance, we cloned and sequenced 21 PCR products. All but one contained a terminal poly(A) sequence, presumably derived from the anchored primer, and an AT-rich region 20 to 40 bases upstream, typical of $3^{\prime}$ untranslated mRNA regions. The sequence of PCR product $10 \mathrm{~A}$ was identical to that of $11 \mathrm{~B}$, and that of $1 \mathrm{E}$ was identical to that of 4D.

Eleven PCR products were 94 to $100 \%$ identical over their entire length to existing Arabidopsis EST, cDNA, or genomic sequences. These represent up to $250 \mathrm{bp}$ of the $3^{\prime}$ ends of transcripts from previously identified Arabidopsis genes. Two PCR products, $6 \mathrm{~A}$ and $11 \mathrm{~F}$, did not match any Arabidopsis sequences at a DNA level but contained open reading frames (ORFs) long enough to allow us to identify amino acid homologies to non-Arabidopsis genes (see below). The remaining sequences gave no meaningful homologies. The results of the sequence analyses are summarized in Table 1. Accession numbers, percent homologies, and nucleotide location of the match are given for any existing sequences that match PCR products.

Of the clones that were unambiguously up-regulated in CaMV-infected and/or transgenic plants, 10A/11B aligned with an AT-rich region of Arabidopsis TAC clone K19B1 (Table 1), presumably the $3^{\prime}$ end of an unreported gene. K19B1 contains three in-frame ORFs within the $2 \mathrm{kbp}$ upstream of the 10A/11B sequence. Using PCR primers flanking the ORFs, we were able to amplify a sequence of $1,211 \mathrm{bp}$ from a cDNA library. This (reported as accession no. AJ011669) lacked the two introns but was otherwise 99\% identical to the genomic sequence. It encodes a previously unreported 352 amino acid protein with a 118 amino acid consensus $m y b$ domain at the $\mathrm{N}$ terminus, a central serine- and threonine-rich domain, and C-terminal domain with (50\%) homology to Arabidopsis myb hsr-1 protein. The C-terminal domain also shows more distant homologies to Arabidopsis myb Y13 protein and Antirrhinum majus myb 306 protein (see Table 1 for accession numbers). 

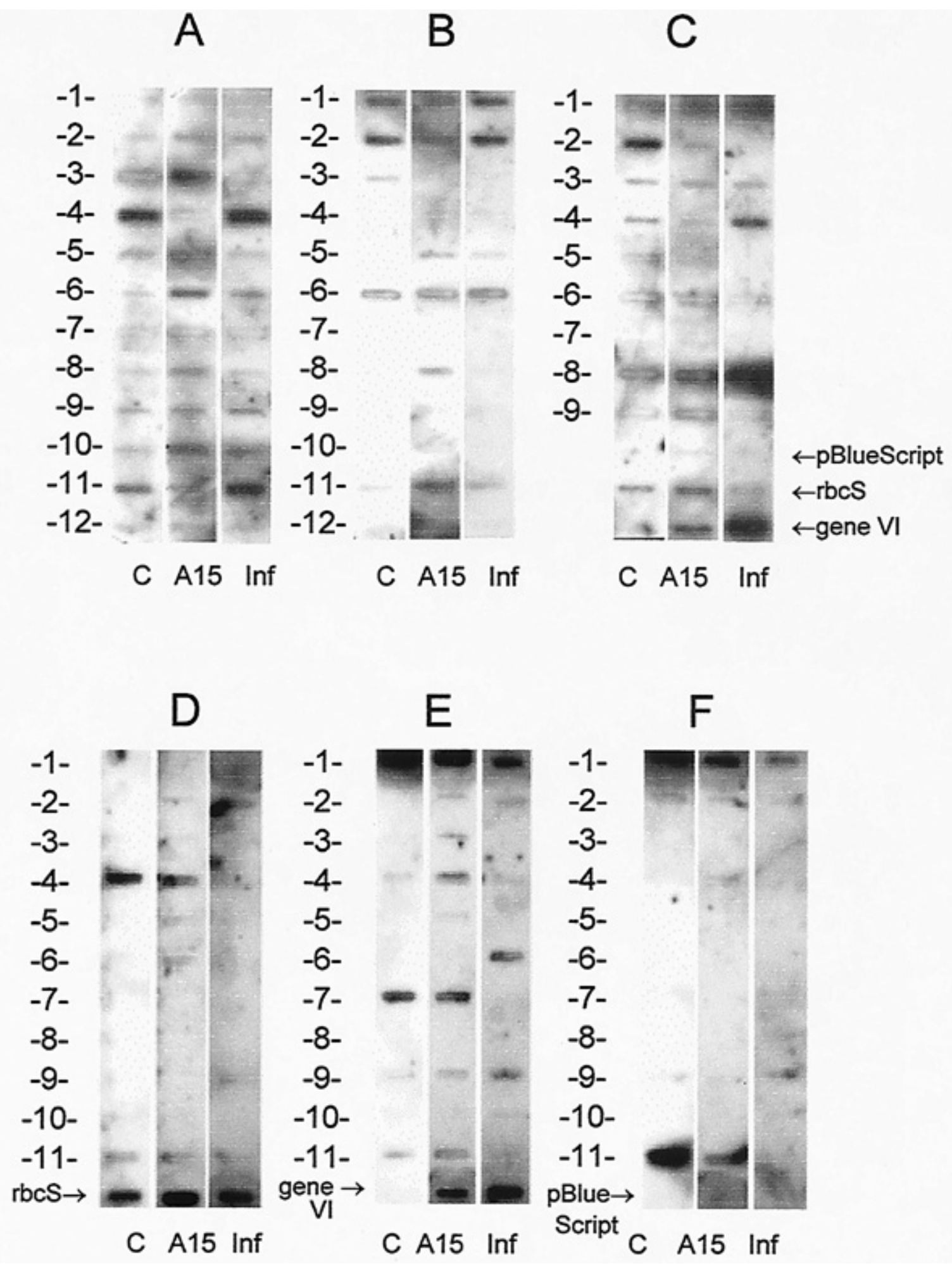

Fig. 1. Typical results of slot-blot hybridizations of amplified cDNA probes to polymerase chain reaction (PCR) products from differential display (DD)PCR gels. DNA samples were applied to the filters in $3 \times 36$ arrays, each filter containing 33 PCR products plus 3 plasmid controls, pBluescript, $r b c S$, and gene VI. Replicate filters were hybridized to the three probes; results shown are after $48 \mathrm{~h}$ of exposure to X-ray film. To facilitate comparison between the three probes, the images have been re-arranged so as to present, in adjacent columns of slots, each PCR product hybridized to the three amplified cDNA probes as indicated under each column: (C) uninfected, nontransgenic controls; (A15) gene VI transgenic plants of line Baji-A15; (Inf) nontransgenic plants infected with cauliflower mosaic virus. Individual PCR products are identified by the numbers at the left of each set and the letters at the top of each set. 
5E matched an unidentified Arabidopsis EST and with the $3^{\prime}$ end of Arabidopsis hypothetical gene F2P3.15. These sequences show potentially significant homology (45\% similarity) to dynactin large subunit. 2E matched with an Arabidopsis cDNA for a vacuolar ATPase, 3E with an Arabidopsis EST with homology to a fungal elicitor-inducible S-adenosyl methionine synthetase from parsley (Kawalleck et al. 1992), and $4 \mathrm{E}$ with a glycine-rich protein (de Oliveira et al. 1990). The 6A sequence (reported as accession no. ATH9555) contained a single ORF encoding 162 amino acids, the C-terminal 82 of which were very highly homologous (84\% identity, 90\% similarity) to the C-terminal derived amino acid sequence of a rice cDNA clone (accession no. D24107), and gave highly significant $\left(E<8 \times 10^{-24}\right)$ matches over the same region to a mouse cDNA clone (48\% identity, $70 \%$ similarity; accession no. AA536798), to several other mammalian cDNA clones (e.g., AA304596, U90904, N25252, and AA004361), and to a region of a Drosophila melanogaster genomic clone (56\% identity, 75\% similarity; accession no. AC005108).

Of the species that were unambiguously down-regulated in infected and/or transgenic plants, $2 \mathrm{~F}$ aligned to the $3^{\prime}$ end of a cDNA clone encoding a putative RNA-binding protein with a glycine-rich C-terminal domain (Van Nocker and Vierstra 1993). 4D/1E aligned to an Arabidopsis cold-inducible protein cDNA (Kiyosue et al. 1994). 11A, which was strongly downregulated in transgenic plants, aligned to the $3^{\prime}$ end of an Arabidopsis EST with homology to actin depolymerization factor. 11F (reported as accession no. ATH6409), which was

Table 1. Hybridization of amplified cDNA probes to polymerase chain reaction (PCR) products on slot blots

\begin{tabular}{|c|c|c|c|c|}
\hline Product $^{\mathrm{a}}$ & $\mathbf{A 1 5}^{\mathbf{b}}$ & Inf. $^{b}$ & Homologies & Homologues and accession nos. $^{c}$ \\
\hline $2 \mathrm{~A}$ & 0 & 0 & & \\
\hline $3 \mathrm{~A}$ & ++ & 0 & None in data base & Not reported \\
\hline $4 \mathrm{~A}$ & -- & 0 & None in data base & Not reported \\
\hline $5 \mathrm{~A}$ & 0 & - & & \\
\hline $6 \mathrm{~A}$ & ++ & ++ & $\begin{array}{l}\text { Amino acid sequence homology to highly conserved domain in rice, human, mouse, } \\
\text { and Drosophila, function unknown }\end{array}$ & ATH9555 \\
\hline $8 \mathrm{~A}$ & + & 0 & & \\
\hline $10 \mathrm{~A}$ & ++ & ++ & $\begin{array}{l}\text { Genomic TAC clone K19B1, unreported gene, } 5^{\prime} \text { myb domain, } 3^{\prime} \text { homology to Arabi- } \\
\text { dopsis myb-hsr1 protein involved in HR }\end{array}$ & $\begin{array}{l}\text { AJ011669, } A B 015469(19176- \\
\quad 18941 ; 98 \%)\end{array}$ \\
\hline $11 \mathrm{~A}$ & - - & + & Arabidopsis EST, similar to actin depolymerization factor & Z17553 (205-331: 97\%) \\
\hline 1B & - & 0 & & \\
\hline 2B & - & 0 & & \\
\hline 3B & -- & -- & None in data base & Not reported \\
\hline $5 \mathrm{~B}$ & ++ & ++ & & \\
\hline $8 \mathrm{~B}$ & ++ & + & & \\
\hline 11B & ++ & ++ & Identical to $10 \mathrm{~A}$ & See $10 \mathrm{~A}$ \\
\hline $1 \mathrm{C}$ & + & + & & \\
\hline $2 \mathrm{C}$ & -- & -- & None in data base & Not reported \\
\hline $4 \mathrm{C}$ & -- & ++ & None in data base & Not reported \\
\hline $5 \mathrm{C}$ & -- & -- & & \\
\hline $8 \mathrm{C}$ & 0 & ++ & None in data base & Not reported \\
\hline $9 \mathrm{C}$ & 0 & 0 & & \\
\hline 2D & + & + & & \\
\hline 3D & + & + & & \\
\hline 4D & - & -- & Arabidopsis mRNA ERD10 dehydration-inducible protein & ATHERD10 (798-1024; 99\%) \\
\hline 5D & + & 0 & Arabidopsis cold-inducible glycine-rich protein & ATHCCRA $(752-853 ; 99 \%)$ \\
\hline 6D & + & 0 & & \\
\hline 9D & 0 & + & & \\
\hline 10D & - & - & Arabidopsis EST, similar to tomato ascorbate free radical reductase & $T 21420(149-230 ; 98 \%)$ \\
\hline 11D & 0 & - & & \\
\hline $1 \mathrm{E}$ & - & -- & Identical to 4D & See 4D \\
\hline $2 \mathrm{E}$ & ++ & ++ & Arabidopsis vacuolar ATPase & ATU65638 (2081-2184; 100\%) \\
\hline $3 \mathrm{E}$ & ++ & 0 & Arabidopsis EST, similar to parsley S-adensoyl methionine sythetase & Z29938 (343-422; 98\%) \\
\hline $4 \mathrm{E}$ & ++ & 0 & Arabidopsis glycine-rich protein & S47409(551-667; 100\%) \\
\hline $5 \mathrm{E}$ & ++ & 0 & Hypothetical gene F2P3.15, Arabidopsis BAC clone F2P3 & AF080120 (51402-51485; 100\%) \\
\hline $6 \mathrm{E}$ & 0 & ++ & & \\
\hline $7 \mathrm{E}$ & 0 & -- & & \\
\hline $9 \mathrm{E}$ & 0 & + & & \\
\hline $11 \mathrm{E}$ & 0 & - & & \\
\hline $1 \mathrm{~F}$ & - & -- & Hypothetical gene $18 \mathrm{~F} 4.80$, Arabidopsis BAC $18 \mathrm{~F} 4$ & $A L 021637(39608-38832 ; 94 \%)$ \\
\hline $2 \mathrm{~F}$ & -- & -- & Arabidopsis glycine-rich, RNA-binding protein, GRP7_ARATH & Z14987(617-747; 99\%) \\
\hline $4 \mathrm{~F}$ & + & + & & \\
\hline $9 \mathrm{~F}$ & 0 & + & & \\
\hline $11 \mathrm{~F}$ & -- & -- & $\begin{array}{l}\text { Amino acid sequence contains sulfotransferase domain. Closest homology to phenol- } \\
\text { sulfotransferases }\end{array}$ & ATH6409 \\
\hline
\end{tabular}

\footnotetext{
${ }^{\mathrm{a}}$ Bands that failed to give a hybridization signal $(1 \mathrm{~A}, 7 \mathrm{~B}, 9 \mathrm{~B}, 10 \mathrm{~B}, 12 \mathrm{~B}, 7 \mathrm{C}, 1 \mathrm{D}, 7 \mathrm{D}, 8 \mathrm{D}, 8 \mathrm{E}, 10 \mathrm{E}, 3 \mathrm{~F}, 5 \mathrm{~F}, 6 \mathrm{~F}, 7 \mathrm{~F}, 8 \mathrm{~F}, 10 \mathrm{~F})$ or for which probes from uninfected, infected, and transgenic plants gave similar levels of hybridization (7A, 9A, 6B,12A, 5B, 3C, 6C) have been omitted.

${ }^{b}$ Intensity of the hybridization signal in infected (Inf) and transgenic (A15) plants relative to uninfected controls is indicated by (++) strongly increased, $(+)$ weakly increased, (- $)$ strongly decreased, (-) weakly decreased, (0) similar.

${ }^{c}$ Accession numbers for Arabidopsis sequences not previously reported are given in bold. Where sequences matched exactly to previously reported Arabidopsis sequences, the accession numbers are indicated in italics, with the nucleotide positions and percent homology of the match in parentheses.
} 
very strongly down-regulated in infected plants (see Figure 2), contained an ORF of 279 bp encoding a consensus sulfotransferase domain (Weinshiboum and Otterness 1994), and showed very significant amino acid homology $(>50 \%$ similarity) to a series of mammalian and plant phenol, hydroxysteroid, estrogen, and flavonol sulfotransferases.

Of the species that showed more modest changes in abundance, 5D matched the $3^{\prime}$ end of an Arabidopsis cDNA clone for a glycine-rich protein (Carpenter et al. 1994), and 10D matched an Arabidopsis EST with homology to a woundinducible, tomato ascorbate, free radical reductase cDNA (Grantz et al. 1995). 1F aligned with part of a putative 2,581bp intron of hypothetical gene $18 \mathrm{~F} 4.80$ on Arabidopsis BAC (bacterial artificial chromosome) clone $18 \mathrm{~F} 4$. It is unclear whether clone $1 \mathrm{~F}$ represents an unidentified gene or an alternative splice product.

\section{Confirmation by Northern blot analysis of mRNA abundance.}

Poirier et al. (1997) reported that amplified RNA dot blots gave estimates of RNA abundance that were consistent with data from Northern (RNA) blots. Nevertheless, to confirm the reliability of the slot blots, we tested 8 selected PCR products as probes in Northern blot hybridizations (Fig. 2). 11F hybridized to an mRNA of approximately 800 bases that was abundant in uninfected control plants, less abundant in Baji-A15, and almost undetectable in CaMV-infected leaves. 6A hybridized to two mRNA species. One of 1,000 bases was equally abundant in all three sets of plants; however, the second transcript of 1,200

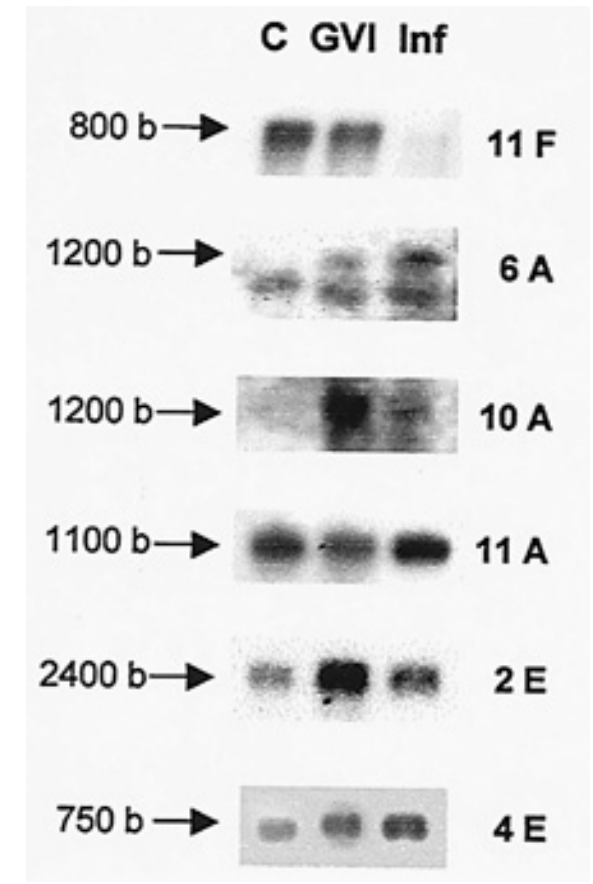

Fig. 2. Northern (RNA) blots of $5 \mathrm{~g}$ of total RNA from: (C) uninfected, non-transgenic controls; (GVI) gene VI transgenic plants; (Inf) nontransgenic plants infected with cauliflower mosaic virus. ${ }^{32} \mathrm{P}$-labeled probes were (from top); $11 \mathrm{~F}$ differential display-polymerase chain reaction (DD-PCR) product, 6A DD-PCR product, 10A/11B cDNA clone, $11 \mathrm{~A}$ cDNA clone, $2 \mathrm{E}$ cDNA clone, 4E cDNA clone. Arrows indicate approximate sizes of the bands based on their migration relative to the $18 \mathrm{~S}$ and $28 \mathrm{~S}$ rRNAs. bases was present in transgenic and infected plants, but absent in the uninfected controls. Results from these Northern blots were consistent with results from the slot blots.

Surprisingly, we were unable to persuade PCR products $2 \mathrm{~A}$, 4A, 10A, 11A, and 2E to hybridize under any conditions, and $4 \mathrm{E}$ hybridized only very faintly (data not shown). Having identified 10A, 11A, 2E, and $4 \mathrm{E}$ from their sequences (see below), we PCR amplified parts of the corresponding clones from a cDNA library, and used these as probes in Northern blots (Fig. 2). Probes for 11A and 4A encompassed the entire ORFs from the cDNAs. The probes for $2 \mathrm{E}$ and $10 \mathrm{~A} / 11 \mathrm{~B}$ contained only part of the coding regions; in the latter case the conserved myb domain was omitted to avoid crosshybridization. For $10 \mathrm{~A}$ and $2 \mathrm{E}$, estimates of transcript abundance in transgenic and infected plants, relative to uninfected, nontransgenic controls, were broadly in agreement with the slot-blot hybridization data, but $11 \mathrm{~A}$ and $4 \mathrm{E}$ were only partially consistent. For 11A mRNA we were able to confirm the down-regulation in transgenic plants, but we did not detect any significant difference in abundance in infected plants. $4 \mathrm{E}$ mRNA appeared to be more abundant in both transgenic and infected plants in Northern blots, although the slot blots detected up-regulation in transgenic plants only.

\section{DISCUSSION}

We have used DD-PCR as a strategy to determine whether alterations in host gene expression induced by virus infection and by transgenic expression of a viral pathogenic determinant were similar. We identified 149 candidate bands by DD-PCR; expression of P6 thus appears to have a wide-ranging effect on the abundance of many mRNA species. In order to confirm that the differences in expression were authentic, we employed a modification of the dot-blot hybridization procedure of Poirier et al. (1997). Using the original procedure for probe synthesis, we had difficulty in producing enough probe to hybridize detectably with any but the most abundant species. Our technique is simple, yields copious amounts of high specific activity, single-stranded probe, and avoids differential amplification (Rosner et al. 1994).

DD-PCR is notorious for producing apparently differentially expressed bands that subsequently turn out to be artefacts (Luce and Burrows 1998; Zegzouti et al. 1997). We were able to confirm by slot-blot hybridization that most of the PCR products represented transcripts that showed at least modest differences in abundance. There is anecdotal evidence that many species identified as differentially expressed by DD-PCR cannot be confirmed as such by Northern blot analysis. These are commonly dismissed as very low abundance mRNAs. The majority of our PCR products did not hybridize when used as probes in Northern blots, but the corresponding cDNA clones hybridized efficiently. These PCR products were smaller than $250 \mathrm{bp}$ and consisted of AT-rich 3' untranslated regions of mRNAs, whereas the cDNA clones and PCR products that did hybridize contained substantial portions of coding sequence (see below). Possibly, short filter-bound (AT-rich) sequences are better targets for relatively long probe sequences than are long filterbound sequences targets for short probe sequences. Northern blots gave estimates of mRNA abundance that were broadly in agreement with those based on slot blots, albeit with mi- 
nor discrepancies. This gives us confidence in our slot-blot hybridization data for those transcripts that appeared to undergo large changes in abundance. However, those species that showed only limited changes in abundance will require additional experimental confirmation.

Although many of the transcripts showed corresponding alterations in abundance in transgenic and infected plants, there were some differences. This is not surprising, since host responses to CaMV infection may not be exclusively attributable to the expression of P6, and in any case transgenic and infected plants are likely to differ in the timing and tissue specificity of P6 expression.

Transgene-mediated expression of a virus gene, CaMV gene VI, induces a symptomlike phenotype in the absence of infection (Baughmann et al. 1988; Goldberg et al. 1991; Cecchini et al. 1997). Similar phenomena have been reported recently for genes from plant viruses from other families, including the gemini- and tospoviruses (Krake et al. 1998; Duan et al. 1997; Prins et al. 1997). Our results indicate that transgenic plants expressing a viral pathogene (Cecchini et al. 1997) mimic infected plants in terms of gene regulation, and can serve as model systems with which to investigate symptom responses. Expression of P6 during infection must be a major factor regulating host gene expression.

Although there has been much recent progress characterizing incompatible virus infection (Bol et al. 1996; Hunt and Ryals 1996), less is known about host gene expression during compatible interactions. In cells at the invasion front of pea seed-borne mosaic potyvirus, several genes appeared to be coordinately up-regulated. These include HSP70 genes and polyubiquitin genes. Other genes, including those for lipoxygenase and heat shock cognate proteins, were down-regulated (Wang and Maule 1995; Aranda et al. 1996). Down-regulation appeared to be part of a general suppression of host gene expression, possibly involving degradation of host mRNAs (Aranda et al. 1996). Our results, with an unrelated virus, provide further evidence for co-ordinate up- and down-regulation of plant genes during virus infection.

We have been able to identify from the data base 13 Arabidopsis genes whose expression appears to be regulated by infection. Several of these have been reported to be also stress or pathogen inducible. Of the 8 genes not yet in the Arabidopsis data base, we have been able to assign a putative function to two, 10A/11B and 11F. Another, 6A, whose C-terminal amino acid sequence is highly conserved between plants, mammals, and D. melanogaster, appears to be a member of a previously unrecognized family of unknown function.

$11 \mathrm{~F}$ showed $>50 \%$ sequence similarity to the C-terminal amino acids of mammalian phenol sulfotransferases, hydroxysteroid sulfotransferases, and estrogen sulfotransferases (PSTs, HSTs, and ESTs, e.g., Loci SUAC_RAT, SUOE_BOVIN, SUO2_RAT, and SUHA_RAT: Rikke and Roy 1996; Nash et al. 1988; Nagata et al. 1993; Ogura et al. 1990), to flavonol sulfotransferases (FSTs) of Flaveria chloraefolia and $F$. bidentis (Loci F3ST_FLACH and F4ST_FLACH: Ananvoranich et al. 1994; Varin et al. 1995), and to brassinosteroid sulfotransferases (BSTs) of Brassica napus (AF000307, AF000306, and AF000305). 11F appears to be a member of a novel class of plant sulfotransferases, since CLUSTAL and PILEUP group it with neither the Flaveria FSTs, the B. napus BSTs, nor a previously reported
Arabidopsis flavonol-like ST (Lacomme and Roby 1996), but with the mammalian PSTs.

The up- and down-regulation of genes encoding proteins with potential regulatory functions is consistent with the hypothesis that the response to infection by compatible viruses involves a program of changes in gene expression. Two of these genes, the 10A/11B myb protein, and the 11F sulfotransferase may form part of a more general response to pathogen infection (see accession no. AJ007289; Lacomme and Roby 1996). Yang and Klessig (1996) have identified a myb gene whose expression is up-regulated by TMV in a resistant but not a susceptible tobacco cultivar.

We have identified 17 mRNAs whose abundance is regulated by CaMV infection, plus a further 13 that show less clear-cut changes in abundance, the significance of which is not so clear. We expect that an exhaustive study would detect many more. Systemically infected plants must undergo wideranging alterations in gene expression, some of which may form part of programmed responses to infection. Identification of genes whose expression is altered by pathogen elicitors will provide us with possible targets for "knock-out" experiments to determine their possible role in host-virus interactions.

\section{MATERIALS AND METHODS}

\section{Transgenic plants and virus infections.}

Transgenic Arabidopsis lines Baji-A15 and Baji-A7, which express high levels of the P6 protein from the recombinant CaMV strain Baji-31, have been described previously (Cecchini et al. 1997). Plants of the nontransgenic parent, Arabidopsis Landsberg erecta $g l l$, were grown and inoculated with CaMV (isolate Cabb B-JI) according to Cecchini et al. (1998).

\section{DD reverse transcription PCR.}

Infected plants were harvested for RNA extraction 15 to 20 days post inoculation, at which time they were exhibiting typical symptoms of crinkling and vein clearing. RNA was purified from pooled leaf tissue of uninfected control, transgenic, and CaMV-infected plants with a Purescript kit (Flowgen, Shenstone, Staffs, UK). To remove any potential DNA contaminants, RNA was treated with DNase I (MessageClean kit, GenHunter Corp., Nashville, TN).

DD-PCR was carried out with an RNAimage kit No. 3 (GenHunter) according to the manufacturer's instructions but with some modifications. First-strand cDNA synthesis was carried out in triplicate with three different 1-base anchored primers $\left(\mathrm{H}-\mathrm{T}_{11}\right)$. Reactions $(20 \mu \mathrm{l})$ containing $500 \mathrm{ng}$ of total RNA, $20 \mu \mathrm{M}$ dNTPs, $0.2 \mu \mathrm{M} \mathrm{H}_{-1} \mathrm{~T}_{11}$ primer, $100 \mathrm{U}$ MMTV reverse transcriptase, $25 \mathrm{mM}$ Tris- $\mathrm{HCl} \mathrm{pH} 8.3,37 \mathrm{mM} \mathrm{KCl}$, $1.5 \mathrm{mM} \mathrm{MgCl}_{2}$, and $5 \mathrm{mM}$ DTT (dithiothreitol) were preincubated at $65^{\circ} \mathrm{C}$ for $5 \mathrm{~min}$, then at $37^{\circ} \mathrm{C}$ for $10 \mathrm{~min}$ before addition of the reverse transcriptase, then a further $1 \mathrm{~h}$ at $37^{\circ} \mathrm{C}$, followed by $5 \mathrm{~min}$ at $75^{\circ} \mathrm{C}$. cDNA was amplified by PCR with one of eight 13-mers (H-AP primers) in combination with one of the three anchored $\mathrm{H}-\mathrm{T}_{11}$ primers. Reactions $(10 \mu \mathrm{l})$ contained $2 \mu \mathrm{M}$ dNTPs, $0.2 \mu \mathrm{M}$ H-AP primer, $0.2 \mu \mathrm{M}$ $\mathrm{H}-\mathrm{T}_{11} \mathrm{M}$ primer, $2 \mu \mathrm{l}$ of first-strand cDNA reaction mix, $0.5 \mathrm{U}$ Taq polymerase (Boehringer Mannheim UK, Lewes, UK), 10 $\mathrm{mM}$ Tris- $\mathrm{HCl} \mathrm{pH} 8.4,50 \mathrm{mM} \mathrm{KCl}, 1.5 \mathrm{mM} \mathrm{MgCl}_{2}$, and $0.001 \%$ gelatin. $\alpha-\left[{ }^{32} \mathrm{P}\right] \mathrm{dCTP}(1 \mu \mathrm{Ci})$ was used instead of $\alpha$ - 
$\left[{ }^{35} \mathrm{~S}\right] \mathrm{dATP}$. The reagents were assembled in $200-\mu \mathrm{l}$ thin-walled tubes (Micro-Tubes; Biogene, Cambridge, UK) and all the PCRs were carried out in an Air Thermo-Cycler (model 1605; Idaho Technology, Idaho Falls, ID), under conditions necessarily modified for rapid cycling. After an initial $94^{\circ} \mathrm{C}$ for 30 $\mathrm{s}, 40$ cycles of amplification were carried out. Each cycle consisted of $15 \mathrm{~s}$ at $94^{\circ} \mathrm{C}, 120 \mathrm{~s}$ at $40^{\circ} \mathrm{C}, 30 \mathrm{~s}$ at $72^{\circ} \mathrm{C}$, temperature slope setting $=3$ (equivalent to a temperature ramping speed of approximately $1^{\circ} \mathrm{C} \cdot \mathrm{s}^{-1}$ ). This was followed by a final hold at $72^{\circ} \mathrm{C}$ for $5 \mathrm{~min}$. DD-PCR products were analyzed on $6 \%$ polyacrylamide sequencing gels.

Dried gels were exposed, without intensifying screens, at room temperature for 4 to $6 \mathrm{~h}$. Bands were excised from the dried gels with a scalpel, after the dried gels were aligned with the X-ray film. DNA was eluted according to the instructions from the RNAimage kit, but with some modifications. Briefly, the gel slice, along with the $3 \mathrm{MM}$ paper, was soaked in $100 \mu \mathrm{l}$ of $\mathrm{dH}_{2} \mathrm{O}$ for $1 \mathrm{~h}$, boiled for $15 \mathrm{~min}$, and then centrifuged in a microcentrifuge for $5 \mathrm{~min}$ to pellet paper and gel debris. The DNA was ethanol precipitated from the supernatant, and resuspended in $10 \mu \mathrm{l}$ of $\mathrm{dH}_{2} \mathrm{O}$. Re-amplification was performed in a total volume of $40 \mu \mathrm{l}$ containing $20 \mu \mathrm{M}$ dNTPs, $0.2 \mu \mathrm{M}$ $\mathrm{H}$-AP primer, $0.2 \mu \mathrm{M} \mathrm{H}-\mathrm{T}_{11} \mathrm{M}$ primer, $4 \mu \mathrm{l}$ of the eluted DNA (either undiluted or diluted 1:10), $0.5 \mathrm{U}$ Taq polymerase, 10 $\mathrm{mM}$ Tris- $\mathrm{HCl} \mathrm{pH} 8.4,50 \mathrm{mM} \mathrm{KCl}, 1.5 \mathrm{mM} \mathrm{MgCl}_{2}$, and $0.001 \%$ gelatin. PCR conditions were as follows: $15 \mathrm{~s}$ at $94^{\circ} \mathrm{C} ; 40$ cycles $\left(10 \mathrm{~s}\right.$ at $94^{\circ} \mathrm{C}, 20 \mathrm{~s}$ at $40^{\circ} \mathrm{C}, 30 \mathrm{~s}$ at $72^{\circ} \mathrm{C}$, temperature slope setting $=3$ ); $5 \mathrm{~min}$ at $72^{\circ} \mathrm{C}$.

Replicate blots were prepared by transferring the amplified DNA (0.5 $\mu \mathrm{g}$ per sample) to Hybond-N nylon membrane (Amersham International, Little Chalfont, UK) under vacuum, with a slot-blot apparatus (Minifold II, Schleicher and Schuell, Dassel, Germany) and then fixed by UV irradiation. The DNA was either denatured on the filter as described by Poirier et al. (1997), or prior to transfer by boiling. Denatured plasmid DNAs from pBluescript II SK ${ }^{-}$(Stratagene, Cambridge, UK), pPvSS191 (Knight and Jenkins 1992), which contains a full length $r b c \mathrm{~S}$ cDNA clone from Phaseolus vulgaris, and pUC-Baji31 (Cecchini et al. 1997), which contains the gene VI coding sequence from CaMV Baji-31 (Cecchini et al. 1998), were applied to each filter as controls.

Probe for amplified RNA screening was prepared essentially as described (Poirier et al. 1997), except that a modified oligonucleotide 5'TCGCGACGGCCAGTGAATTGTAATAC GACTCACTATAGGCGCC $(\mathrm{T})_{15}$, was used as primer for firststrand cDNA synthesis.

For preparation of the amplified cDNA probe, ds cDNA was synthesized from total RNA with a cDNA Synthesis Module kit (Amersham International), essentially as described by Cecchini et al. (1993), but with the T7-oligo(dT) primer described above to prime first-strand cDNA synthesis. Asymmetric amplification of the cDNA was carried out in 50$\mu \mathrm{l}$ reactions containing $40 \mathrm{ng}$ of cDNA, $500 \mathrm{nM}$ T7 primer (5'GTAATACGATCACTATAGGC), $200 \mu \mathrm{M}$ dATP, $200 \mu \mathrm{M}$ dTTP, $200 \mu \mathrm{M}$ dGTP, $12 \mu \mathrm{M}$ dCTP, $100 \mu \mathrm{Ci} \alpha-\left[{ }^{32} \mathrm{P}\right] \mathrm{dCTP}, 5 \mathrm{U}$ Taq polymerase, $50 \mathrm{mM}$ Tris- $\mathrm{HCl} \mathrm{pH} 8.3,2 \mathrm{mM} \mathrm{MgCl}_{2}, 0.5$ to $1.0 \%$ Ficoll, $1 \mathrm{mM}$ Tartrazine, $0.025 \%$ bovine serum albumin. Amplification was carried out in the Air Thermocycler under the following conditions: $30 \mathrm{~s}$ at $94^{\circ} \mathrm{C} ; 35$ cycles $(10 \mathrm{~s}$ at $94^{\circ} \mathrm{C}, 20 \mathrm{~s}$ at $41^{\circ} \mathrm{C}, 80 \mathrm{~s}$ at $72^{\circ} \mathrm{C}$, temperature slope setting $=3$ [equivalent to a ramp speed of $3^{\circ} \mathrm{C} \cdot \mathrm{s}^{-1}$ ]), $5 \mathrm{~min}$ at $72^{\circ} \mathrm{C}$.
Hybridizations were carried out by incubating the blots at $42^{\circ} \mathrm{C}$ with $5 \times \mathrm{SSPE}(1 \times \mathrm{SSPE}$ is $0.18 \mathrm{M} \mathrm{NaCl}, 10 \mathrm{mM}$ $\mathrm{NaPO}_{4}$, and 1 mM EDTA [pH 7.7]), $2 \times$ Denhardt's, $0.1 \%$ SDS (sodium dodecyl sulfate), $100 \mathrm{mg}$ of salmon sperm DNA per $\mathrm{ml}, 50 \%$ formamide, and $5 \times 10^{7} \mathrm{dpm}$ per $\mathrm{ml}$ of amplified cDNA probe. The blots were washed $2 \times 15 \mathrm{~min}$ at $60^{\circ} \mathrm{C}$, in $0.1 \times \mathrm{SSC}(1 \times \mathrm{SSC}$ is $0.15 \mathrm{M} \mathrm{NaCl}$ plus $0.015 \mathrm{M}$ sodium citrate), $0.5 \%$ SDS.

Northern blot hybridizations were carried out as described (Cecchini et al. 1997).

\section{Cloning and DNA sequencing of PCR products.}

PCR products were cloned with a Topo TA cloning kit (Invitrogen, Leek, The Netherlands), and sequenced by MWG Biotech (Milton Keynes, U.K.). Homology searches were carried out with BLAST 2 (Altschul et al. 1997). Alignments were carried out with the CLUSTAL, PILEUP, and PRETTY programs from GCG (version 9.0). Novel nucleic acid sequences have been submitted to the EMBL data base; to save space the accession numbers and loci only are given in this paper.

\section{Isolation of cDNA clones.}

A $\lambda$ ZAP II cDNA library from hypocotyls of 3-day-old seedlings of Arabidopsis Columbia (Kieber et al. 1993) was obtained from the Arabidopsis Biological Resource CenterDNA Stock Center (Columbus, OH). Arabidopsis sequences, identified in the data base as homologous to each DD-PCR product, were used to design PCR primers to amplify nearfull-length sequences from cDNAs with $1 \mu \mathrm{l}\left(10^{6} \mathrm{PFU}\right)$ of phage stock as template for PCR. The PCR-amplified cDNAs were cloned and sequenced as described above.

\section{ACKNOWLEGMENTS}

We should like to thank Kate Griffith for providing us with helpful suggestions and technical details for the DD-PCR and Janet Laird for technical assistance. C. G. was a recipient of a short-term EMBO fellowship and received funding under the British Council MURST scheme during her visits to Glasgow. This work was funded by grants from the BBSRC, numbers P02475 and P09461. Approval for work with transgenic plants was granted by the Glasgow University (Biochemistry and Molecular Biology) GM committee.

\section{LITERATURE CITED}

Al-Kaff, N. S., Covey, S. N., Kreike, M. M., Page, A. M., Pinder, R., and Dale, P. J. 1998. Transcriptional and post-transcriptional plant gene silencing in response to a pathogen. Science 279:2713-2715.

Altschul, S. F., Madden, T. L., Schaffer, A. A., Zhang, J., Zhang, Z., Miller, W., and Lipman, D. J. 1997.Gapped BLAST and PSI-BLAST: A new generation of protein database search programs. Nucleic Acids Res. 25:3389-3402.

Ananvoranich, S., Varin, L., Gulick, P., and Ibrahim, R. 1994. Cloning and regulation of flavonol 3-sulfotransferase in cell-suspension cultures of Flaveria bidentis. Plant Physiol. 106:485-491.

Anderson, E. J., Qiu, S. G., and Schoelz, J. E. 1991. Genetic analysis of determinants of disease severity and virus concentration in cauliflower mosaic virus. Virology 181:647-655.

Aranda, M. A., Escaler, M., Wang, D. W., and Maule, A. J. 1996. Induction of HSP70 and polyubiquitin expression associated with plant virus replication. Proc. Natl. Acad. Sci. USA 93:15289-15293.

Balachandran, S., Hurry, V. M., Kelley, S. E., Osmond, C. B., Robinson, S. A., Rohozinski, J., Seaton, G. G. R., and Sims, D. A. 1997. Concepts of plant biotic stress. Some insights into the stress physiology of virus-infected plants, from the perspective of photosynthesis, Physiol. 
Plant. 1:203-213

Baughmann, G. A., Jacobs, J. D., and Howell, S. H. 1988. Cauliflower mosaic virus gene VI produces a symptomatic phenotype in transgenic tobacco plants. Proc. Natl. Acad. Sci. USA 85:733-737.

Benito, E. P., Prins, T., and Van Kan, J. A. L. 1996. Application of differential display RT-PCR to the analysis of gene expression in a plantfungus interaction. Plant Mol. Biol. 32:947-957.

Bol, J. F., Buchel, A. S., Knoester, M., Baladin, T., Van Loon, L. C., and Linthorst, H. J. M. 1996. Regulation of the expression of plant defence genes. Plant Growth Regul. 18:87-91.

Carpenter, C. D., Kreps, J. A., and Simon, A. E. 1994. Genes encoding glycine-rich Arabidopsis thaliana proteins with RNA-binding motifs are influenced by cold treatment and an endogenous circadian rhythm. Plant Physiol. 104:1015-1025.

Cecchini, E., Al-Kaff, N. S., Bannister, A., Giannakou, M. E., McCallum, D. G., Maule, A. J., Milner, J. J., and Covey, S. N. 1998. Pathogenic interactions between variants of cauliflower mosaic virus and Arabidopsis. J. Exp. Bot. 49:731-737.

Cecchini, E., Dominy, P. J., Geri, C., Sentry, J., Kaiser, K., and Milner, J. J. 1993. Identification of genes up-regulated in Nicotiana glauca pith tissue, using an improved method for constructing a subtractive cDNA library. Nucleic Acids Res. 21:5742-5747.

Cecchini, E., Gong, Z., Geri, C., Covey, S. N., and Milner, J. J. 1997. Transgenic Arabidopsis lines expressing gene VI protein from cauliflower mosaic virus variants exhibit a range of symptom-like phenotypes and accumulate inclusion bodies. Mol. Plant-Microbe Interact. 10:1094-1101.

Covey, S. N., Al-Kaff, N. S., Langara, A., and Turner, D. S. 1997. Plants combat infection by gene silencing. Nature 385:781-782.

Covey, S. N., and Turner, D. S. 1991. Comparison of viral nucleic acid intermediates at early and late stages of cauliflower mosaic virus infection suggests a feedback regulatory mechanism. J. Gen. Virol. 72: 2603-2606,

de Oliveira, D. E., Seurinck, J., Inze, D., Van Montagu, M., and Botterman, J. 1990. Differential expression of five Arabidopsis genes encoding glycine-rich proteins. Plant Cell 2:427-436.

Duan, Y. P., Powell, C. A., Purcifull, D. E., Broglio, P., and Hiebert, E. 1997. Phenotypic variation in transgenic tobacco expressing mutated geminivirus movement/pathogenicity (BC1) proteins. Mol. PlantMicrobe Interact. 10:1065-1074.

Goldberg, K.-B., Kiernan, J., and Shepherd, R. J. 1991.A disease syndrome associated with expression of gene VI of caulimoviruses may be a nonhost reaction. Mol. Plant-Microbe Interact. 4:182-189.

Grantz, A. A., Brumell, D. A., and Bennett, A. B. 1995. Ascorbate free radical reductase mRNA levels are induced by wounding. Plant Physiol. 108:411-418.

Hunt, M. D. J., and Ryals, A. 1996. Systemic acquired resistance signal transduction. Crit. Rev. Plant Sci. 15:583-606.

Kawalleck, P., Plesch, G., Hahlbrock, K., and Somssich, I. E. 1992. Induction by fungal elicitor of S-adenosyl-L-methionine synthetase and S-adenosyl-L-homocysteine hydrolase mRNAs in cultured cells and leaves of Petroselinum crispum. Proc. Natl. Acad. Sci. USA 89:47134717

Kieber, J. J., Rothenberg, M., Roman, G., Feldmann, K. A., and Ecker, J. R. 1993. CTR1, a negative response regulator of the ethylene response pathway in Arabidopsis, encodes a member of the raf family of protein kinases. Cell 72:427-441.

Kiyosue, T., Yamaguchi-Shinozaki, K., and Shinozaki, K. 1994. Characterization of two cDNAs (ERD10 and ERD14) corresponding to genes that respond rapidly to dehydration stress in Arabidopsis thaliana. Plant Cell Physiol. 35:225-231.

Knight, M. R., and Jenkins, G. I. 1992. Genes encoding the small subunit of ribulose 1,5-bisphosphate carboxylase oxygenase in Phaseolus vulgaris - nucleotide sequences of cDNA clones and initial studies of expression. Plant Mol. Biol. 18:567-579.

Krake, L. R., Rezaian, M. A., and Dry, I. B. 1998. Expression of the tomato leaf curl geminivirus $C 4$ gene produces viruslike symptoms in transgenic plants. Mol. Plant-Microbe Interact. 11:413-417.

Lacomme, C., and Roby, D. 1996. Molecular cloning of a sulfotransferase in Arabidopsis thaliana and regulation during development and in response to infection with pathogenic bacteria. Plant Mol. Biol. 30: 995-1008.

Luce, M. J., and Burrows, P. D. 1998. Minimizing false positives in differential display. Biotechniques 24:766.

Nagata, K., Ozawa, S., Miyata, M., Shimada, M., Gong, D. W., Yamazoe, Y., and Kato, R. 1993. Isolation and expression of a cDNA encoding a male-specific rat sulfotransferase that catalyzes activation of $N$-hydroxy-2-acetylaminofluorene. J. Biol. Chem. 268:24720-24725.

Nash, A. R., Glenn, W. K., Moore, S. S., Kerr, J., Thompson, A. R., and Thompson, E. O. 1988. Oestrogen sulfotransferase: Molecular cloning and sequencing of cDNA for the bovine placental enzyme. Aust. J. Biol. Sci. 41:507-516.

Ogura, K., Kajita, J., Narihata, H., Watabe, T., Ozawa, S., Nagata, K. Yamazoe, Y., and Kato, R.. 1990. cDNA cloning of the hydroxysteroid sulfotransferase STa sharing a strong homology in amino acid sequence with the senescence marker protein SMP-2 in rat livers. Biochem. Biophys. Res. Commun. 166:1494-1500.

Poirier, G. M. C., Pyati, J., Wan, J. S., and Erlander, M. G. 1997 Screening differentially expressed cDNA clones obtained by differential display using amplified RNA. Nucleic Acids Res. 25:913-914.

Prins, M., Storms, M. M. H., Kormelink, R., DeHaan, P., and Goldbach, R. 1997. Transgenic tobacco plants expressing the putative movement protein of tomato spotted wilt tospovirus exhibit aberrations in growth and appearance. Transgenic Res. 6:245-251.

Ratcliff, N., Harrison, B. D., and Baulcombe, D. C. 1997. A similarity between viral defense and gene silencing in plants. Science 276:11581560 .

Rikke, B. A., and Roy, A. K. 1996. Structural relationships among members of the mammalian sulfotransferase gene family. Biochim. Biophys. Acta 1307:331-338.

Rosner, A., Maslenin, L., and Spiegel, S. 1994. The use of short and long PCR products for improved detection of prunus necrotic ringspot virus in woody plants. J. Virol. Methods 67:135-141.

Rothnie, H. M., Chaplelaine, Y., and Hohn, T. 1994. Pararetroviruses and retroviruses: A comparative review of viral structure and gene expression strategies. Adv. Virus Res. 44:1-67.

Stratford, R., and Covey, S. N. 1989. Segregation of cauliflower mosaic virus symptom determinants. Virology 172:452-459.

Turner, D. S., McCallum, D. G., and Covey, S. N. 1996. Roles of the $35 \mathrm{~S}$ promoter and multiple overlapping domains in the pathogenicity of the pararetrovirus cauliflower mosaic virus, J. Virol. 70:5414-5420.

Van Nocker, S. R. C., and Vierstra, R. D. 1993. Two cDNAs from Arabidopsis thaliana encode putative RNA binding proteins containing glycine-rich domains. Plant Mol. Biol. 21:695-699.

Varin, L., Marsolais, F., and Brisson, N. S. 1995. Chimeric flavonol sulfotransferases define a domain responsible for substrate and position specificities. J. Biol. Chem. 270:12498-12502.

Wang, D. W., and Maule, A. J. 1995. Inhibition of gene expression associated with plant virus replication. Science 267:229-231.

Weinshiboum, R., and Otterness, D. B. S. 1994. Sulfotransferase enzymes. Pages 45-78 in: Handbook of Experimental Pharmacology: Conjugation Deconjugation Reactions in Drug Metabolism and Toxicity. Vol. 112. F. C. Kauffman, ed. Springer-Verlag, New York.

Yang, Y. O., and Klessig, D. F. 1996. Isolation and characterization of a tobacco mosaic virus-inducible $m y b$ oncogene homolog from tobacco. Proc. Natl. Acad. Sci. USA 93:14972-14977.

Zegzouti, H., Marty, C., Jones, B., Bouquin, T., Latche, A., Pech, J. C., and Bouzayen, M. 1997. Improved screening of cDNAs generated by mRNA differential display enables the selection of true positives and the isolation of weakly expressed messages. Plant Mol. Biol. Rep. 15 236-245.

Zhu, Q., Dabi, T., Beeche, A., Yamamoto, R., Lawton, M. A., and Lamb, C. 1995. Cloning and properties of a rice gene encoding phenyl ammonia lyase. Plant Mol. Biol. 29:535-550. 